\title{
Perancangan Arsitektur Sistem Informasi Pondok Pesantren Dengan The Open Group Architecture Framework (Togaf)
}

\author{
M.Ainul Yaqin', Alfionita Sa'adah², Nanda Nafisah Puspithasari' ${ }^{3}$, Lutfia Miftahur Rahma \\ Jurusan Teknik Informatika, Fakultas Sains dan Teknologi, Universitas Islam Negeri Maulana Malik \\ Ibrahim Malang \\ Jalan Gajayana No. 50 Malang 65144 Telp. +62 (341) 551-354 \\ yaqinov@ti.uin-malang.ac.id, 16650097@student.uin-malang.ac.id, 16650100@student.uin- \\ malang.ac.id, 16650114@student.uin-malang.ac.id
}

\begin{abstract}
Islamic boarding school is a place of learning in which there are very many facilities and services. Good mastery of language, creativity, religion, leadership and all kinds of knowledge must already exist in the boarding school. The current condition of many Islamic boarding schools does not yet have a specific and integrated information system architecture in Islamic boarding schools in accordance with the needs and objectives of Islamic boarding schools, the cause is because Islamic boarding schools have not yet focused on the process of developing their information systems. Therefore we need an information system in Islamic boarding school. In this study the author raised the information system design of Islamic boarding school by using TOGAF (The Open Group Architecture Framework) with the Architecture Development Method (ADM) method. The output that can be achieved from the design of Islamic Boarding School Information System is to produce a model and basic framework (blue print) in developing integrated boarding school information systems to support the needs of Islamic Boarding Schools.
\end{abstract}

Keywords: Boarding School Information System, TOGAF, TOGAF ADM

\begin{abstract}
Abstrak
Pondok Pesantren merupakan tempat pembelajaran yang didalamnya sangat banyak fasilitas maupun pelayanan. Penguasaan baik bahasa, kreatifitas, agama, kepemimpinan dan segala jenis keilmuan sudah harus ada dalam pondok pesantren. Kondisi saat ini banyak pondok pesantren belum memiliki arsitektur sistem informasi pondok pesantren yang spesifik dan terintegrasi sesuai dengan kebutuhan dan tujuan pihak pesantren, penyebabnya karena memang Pondok Pesantren belum fokus terhadap proses pengembangan sistem informasinya. Oleh sebab itu diperlukan sistem informasi di Pondok Pesantren. Pada penelitian ini penulis mengangkat tentang perancangan sistem informasi pondok pesantren dengan menggunakan TOGAF (The Open Group Architecture Framework) dengan metode Architecture Development Method (ADM). Keluaran yang dapat dicapai dari perancangan Sistem Informasi Pondok Pesantren adalah menghasilkan model dan kerangka dasar (blue print) dalam mengembangkan sistem informasi pondok pesantren yang terintegrasi untuk mendukung kebutuhan Pondok Pesantren.
\end{abstract}

Kata kunci: Sistem Informasi Pondok Pesantren, TOGAF, TOGAF ADM

\section{PENDAHULUAN}

Pada aktivitas pembelajaran di pondok pesantren seharusnya memiliki suatu sistem informasi yang tepat dan sesuai standar pondok pesantren. Namun kebanyakan dari sistem informasi di pondok pesantren sering terjadi tumpang tindih fungsi dan kurang optimal akan pelayanan. Untuk mengatasi hal itu pondok pesantren tidak cukup hanya memiliki sistem informasi saja, namun harus memiliki arsitektur sistem informasi yang sesuai dengan standar agar seluruh 
aktivitas bisa berjalan dengan lancar. Setiap sistem informasi memiliki perbedaan antara pondok pesantren satu dengan yang lainnya, hal ini dikarenakan antar pondok pesantren memiliki aktivitas yang berbeda pula.

Dalam perancangan arsitektur sistem informasi terdapat beberapa metode diantaranya adalah adalah Zachman, TOGAF, FEAF dan TEAF. Namun pada jurnal kali ini penulis menggunakan metode TOGAF untuk merancang sistem informasi pondok pesantren. TOGAF dikembangkan oleh The Open Group Architecture Framework pada tahun 1995. Awalnya TOGAF digunakan oleh Departemen Pertahanan Amerika Serikat namun pada perkembangannya TOGAF banyak digunakan pada berbagai bidang seperti perbankan, industri manufaktur dan juga pendidikan. TOGAF ini digunakan untuk mengembangkan Enterprise Architecture, dimana terdapat metode dan tools yang detail untuk mengimplementasikannya, hal inilah yang membedakan dengan Framework EA lain misalnya Framework Zachman. TOGAF memberikan metode yang detail bagaimana membangun dan mengelola serta mengimplementasikan arsitektur enterprise dan sistem informasi yang disebut dengan Architecture Development Method (ADM).

Dalam perencanaan arsitektur sistem informasi ini juga disusun menggunakan perkembangan standarisasi pondok pesantren. Terdapat sejumlah 52 standarisasi pondok pesantren yang menjadi arahan dalam membangun arsitektur enterprise sistem informasi. Fokus dari penelitian ini yaitu bagaimana merancang arsitektur sistem informasi pondok pesantren menggunakan metode TOGAF dengan perkembangan standarisasi pondok pesantren. Oleh karena itu, hasil dalam penelitian ini diharapkan dapat menghasilkan suatu arsitektur sistem informasi yang dapat digunakan sebagai pedoman dalam pembangunan sistem informasi di pondok pesantren maupun asrama pendidikan islam lainnya yang sesuai dengan kebutuhan dan tujuan organisasi.

\section{METODOLOGI PENELITIAN}

\subsection{Dasar Teori}

Tabel 1. Penelitian Terkait

\begin{tabular}{|l|l|l|l|l|}
\hline No & Penelitian & Objek & Metode & \multicolumn{1}{|c|}{ Hasil } \\
\hline 1 & $\begin{array}{l}\text { Suhendri, } \\
2015\end{array}$ & $\begin{array}{l}\text { Perancangan arsitektur } \\
\text { sistem informasi Pondok } \\
\text { Pesantren Ar-Rahmat }\end{array}$ & Togaf ADM & $\begin{array}{l}\text { Penelitian ini menghasilkan model } \\
\text { dan kerangka dasar (blue print) } \\
\text { dalam mengembangkan sistem } \\
\text { informasi sekolah yang terintegrasi } \\
\text { untuk mendukung kebutuhan } \\
\text { Pondok Pesantren [1]. }\end{array}$ \\
\hline 2 & $\begin{array}{l}\text { Hasbu Naim } \\
\text { Syaddad, }\end{array}$ & $\begin{array}{l}\text { Perancangan Model } \\
\text { Arsitektur Sistem } \\
\text { Informasi Di Perguruan } \\
\text { Tinggi Menggunakan } \\
\text { Togaf }\end{array}$ & Togaf ADM & $\begin{array}{l}\text { Pemodelan arsitektur sistem } \\
\text { informasi yang dibuat terdiri dari } \\
\text { 35 entitas data dari 7 fungsi bisnis } \\
\text { dan 36 aplikasi [2]. }\end{array}$ \\
\hline 3 & $\begin{array}{l}\text { Riza } \\
\text { Kurniawan, }\end{array}$ & $\begin{array}{l}\text { Perancangan Arsitektur } \\
\text { Enterprise Pondok }\end{array}$ & Togaf ADM & $\begin{array}{l}\text { Dari fase-fase yang ada di dalam } \\
\text { TOGAF ADM, diperoleh 7 area }\end{array}$ \\
\hline
\end{tabular}




\begin{tabular}{|l|l|l|l|l|}
\hline 2015 & $\begin{array}{l}\text { Pesantren Salafiyah } \\
\text { Syafi'iyah Situbondo } \\
\text { Dengan Standar Togaf }\end{array}$ & $\begin{array}{l}\text { fungsional utama, 95 fungsional } \\
\text { bisnis, 211 entitas data dan 92 } \\
\text { kandidat aplikasi yang } \\
\text { dikembangkan untuk mendukung } \\
\text { proses bisnis di Pondok Pesantren } \\
\text { Salafiyah Syafi'iyah Situbondo [3]. }\end{array}$ \\
\hline 4 & $\begin{array}{l}\text { Irmayanti \& } \\
\text { Permana, }\end{array}$ & $\begin{array}{l}\text { Perencanaan arsitektur } \\
\text { enterprise sistem } \\
\text { informasi Dinas Tenaga } \\
\text { Kerja, Sosial, dan } \\
\text { Transmigrasi }\end{array}$ & Togaf ADM & $\begin{array}{l}\text { Berupa blue print arsitektur bisnis, } \\
\text { arsitektur data, arsitektur aplikasi } \\
\text { yang menghasilkan lima aplikasi } \\
\text { lama yaitu IPK, SIMPKH, SIMDA, } \\
\text { SISKOTKLN, dan TKA online, } \\
\text { serta 23 aplikasi baru. Selain itu, } \\
\text { dihasilkan pula arsitektur teknologi } \\
\text { berupa arsitektur jaringan sebagai } \\
\text { acuan dalam pembangunan sistem } \\
\text { lebih lanjut, sehingga dapat } \\
\text { menunjang proses bisnis yang ada } \\
\text { di Disnakersostrans Kabupaten } \\
\text { Purwakarta [4]. }\end{array}$ \\
\hline
\end{tabular}

\subsubsection{Sistem Informasi}

Sistem Informasi merupakan gabungan dari manusia, hardware, software, jaringan komunikasi dan data yang saling berinteraksi untuk menyimpan, mengumpulkan, memproses, dan mendistribusikan informasi untuk mendukung pengambilan keputusan dalam suatu organisasi [1]. Suatu sistem informasi dapat didefinisikan secara teknis sebagai seperangkat komponen yang saling terkait yang mengumpulkan (mengambil), memproses, menyimpan, dan mendistribusikan informasi untuk mendukung pengambilan keputusan dan kontrol dalam suatu organisasi. Dalam penelitan ini perencanaan sistem informasi untuk pondok pesantren yang akan dibangun nantinya bertujuan dalam hal memproses, menyimpan dan menghasilkan suatu informasi yang terorganisir dan sesuai kebutuhan pondok pesantren untuk mendukung proses pengambilan keputusan.

\subsubsection{Arsitektur Enterprise}

Enterprise Architecture (EA) adalah gambaran umum mengenai operasional sistem dalam organisasi dari tahap perencanaan hingga implementasi. Arsitektur enterprise memiliki empat komponen utama yaitu: arsitektur bisnis, arsitektur informasi, arsitektur teknologi dan arsitektur aplikasi.

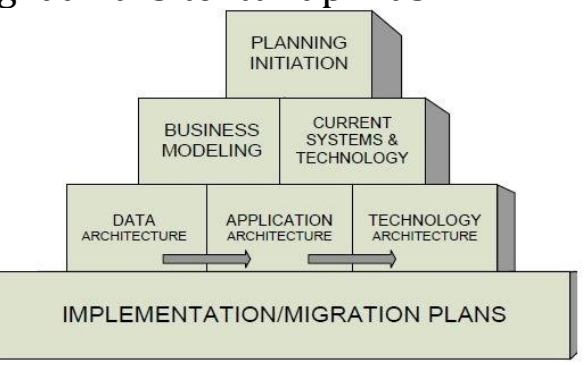

Gambar 1. Lapisan Arsitektur Enterprise 


\subsubsection{TOGAF ADM}

TOGAF ADM merupakan metode generik yang berisikan sekumpulan aktivitas yang digunakan dalam memodelkan pengembangan arsitektur enterprise. Metode ini juga dibisa digunakan sebagai panduan atau alat untuk merencanakan, merancang, mengembangkan dan mengimplementasikan arsitektur sistem informasi untuk organisasi [5].

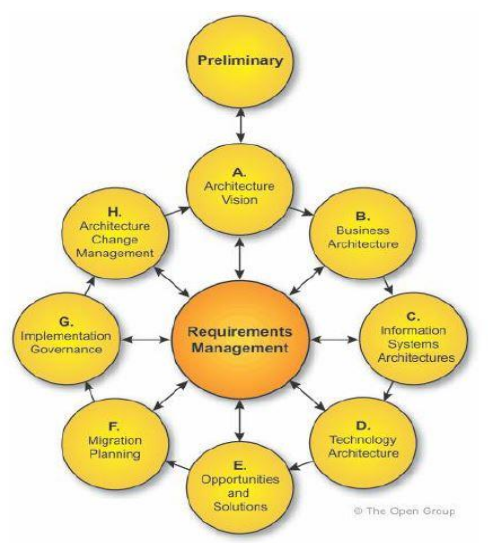

Gambar 2. Framework TOGAF ADM

Struktur dasar TOGAF ADM terdiri dari delapan fase yaitu The Open Group Architecture Framework (TOGAF):

a. Architecture Vision

Tahap ini merupakan tahap penggambaran awal dari pengembangan arsitektur yang mencakup pendefinisian ruang lingkup yang dirancang, visi misi serta profil organisasi.

b. Business Architecture

Fase ini mendefinisikan kondisi awal dalam arsitektur bisnis dengan menentukan arsitektur bisnis dan analisis kesenjangan antara keduanya.

c. Information System Architecture

Fase dimana dibangunnya system informasi dimana meliputi 2 arsitektur yaitu data dan aplikasi. Arsitektur Data melakukan identifikasi entitas data dan menggambarkan asosiasi data dengan proses skema. Sedangkan Arsitektur Aplikasi dibuat berdasarkan kebutuhan dan relevan dengan Enterprise Continum.

d. Technology Architecture

Fase ini merupakan fase dimana pembangunan teknologi yang menjadi dasar implementasi system. Teknologi diproyeksikan dengan penjelasan detail penggunaannya dalam organisasi.

e. Opportunities and Solution

Tahap dimana terjadinya identifikasi dari arsitektur sebelumnya yang digunakan untuk mencapai rancangan arsitektur

f. Migration Planning

Tahap dimana roodmap disusun dan pemilihan proyek-proyek implementasi berdasarkan prioritas utama. 
g. Implementation Governance

Fase yang digunakan untuk menyusun tata laksana implementasi serta menyusun manajemen proyek dalam suatu system.

h. Architecture Change Management

Tahap dimana pembangunan suatu manajemen perubahan bagi dasar arsitektur yang baru.

\subsection{Tahapan Penelitian}

Pada tahap ini menyediakan proses yang dilewati dalam melakukan rancangan arsitektur sistem informasi pondok pesantren. Secara umum tahapan penelitian arsitektur sistem informasi pondok pesantren sebagai berikut:

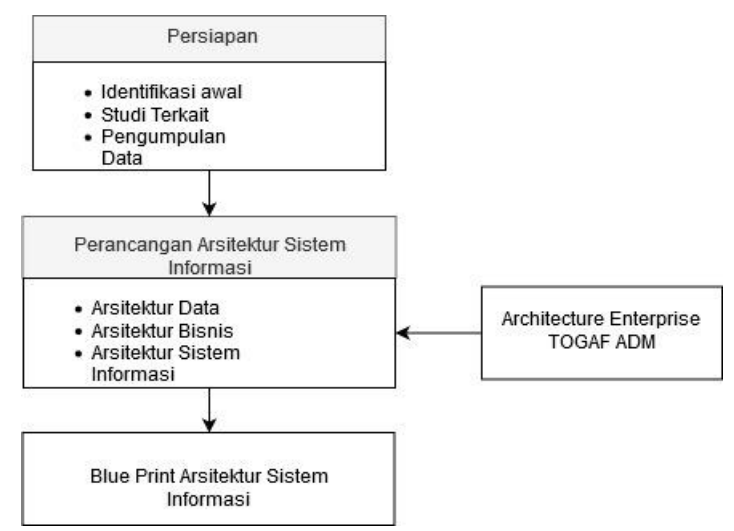

Gambar 3. Tahapan Penelitian

a. Persiapan

Pada tahap ini yaitu pemahaman terhadap identifikasi penelitian, pengumpulan literatur, jurnal, dan pustaka lain terkait dengan tema penelitian, dan pengumpulan data dan dokumen pendukung.

b. Perancangan Arsitektur Sistem Informasi

Sebagai bagian dari penelitian ini, penulis menetapkan 52 standart minimal nasional pada sekolah asrama untuk melakukan perancangan arsitektur sistem informasi pada pondok pesantren ini dengan melakukan wawancara dan observasi kepada pihak terkait yang pernah tinggal di pondok pesantren tertentu. Dalam perancangan struktur organisasi ini terdapat beberapa sistem informasi eksekutif. Sistem informasi eksekutif ini terbagi dalam sistem informasi manajemen dan di dalamnya terdapat detail sistem informasi yang dibutuhkan pada struktur organisasi pondok pesantren [6].

c. Blue Print Arsitektur Sistem Informasi

Pada tahapan terakhir ini, perancangan arsitektur sistem informasi yang sudah dilakukan kemudian disusun dan didokumentasikan ke dalam Cetak Biru (Blueprint) Sistem Informasi.

\section{HASIL DAN PEMBAHASAN}

Fokus hasil dan pembahasan penelitian ini, akan dilakukan perancangan arsitektur sistem informasi dengan pendekatan Enterprise Architecture (EA) 
menggunakan metode TOGAF ADM. Dalam proses perancangan arsitektur sistem informasi, disusun berdasarkan 52 standarisasi pondok pesantren yang telah penulis sederhanakan.

\subsection{Preliminary Phase}

Fase Preliminary merupakan fase awal yang merupakan persiapan sebelum merencanakan sebuah arsitektur enterprise, fase ini bertujuan untuk menjelaskan setiap tahapan-tahapan dari kerangka kerja serta metodologi dari setiap perencanaan, melaksanakan tools arsitektur dan prinsip-prinsip Arsitektur Enterprise, yakni dalam menetapkan aktivitas utama dan pendukung.

\subsection{Requirement Management}

Tahapan Requirement Management tujuannya adalah menentukan kebutuhan proses yang ada serta pengelolaan kebutuhan arsitektur enterprise yang mana tahapannya mengidentifikasi seluruh kebutuhan dan kemudian menyimpannya lalu menerapkannya dalam tahapan TOGAF ADM [1].

\subsection{Arsitektur Bisnis}

Penulis melakukan analisis data dari yang didapatkan dengan melakukan analisa kebutuhan arsitektur sistem informasi pada pondok pesantren berdasarkan 52 standarisasi sistem informasi pondok pesantren. Berikut ini stakeholder yang berperan dalam proses bisnis utama dan pendukung.

Tabel 2. Hubungan Stakeholder dengan Organisasi

\begin{tabular}{|c|c|c|}
\hline \multicolumn{3}{|l|}{ Aktivitas/Stakeholder } \\
\hline Utama & Pondok Pesantren & Sasaran \\
\hline $\begin{array}{l}\text { Pengasuh } \\
\text { Pondok Pesantren }\end{array}$ & $\begin{array}{l}\text { Terdiri oleh pendiri pondok pesantren yang } \\
\text { menjadi penanggung jawab }\end{array}$ & \\
\hline Bidang Asrama & \multirow{2}{*}{$\begin{array}{l}\text { Terdiri dari manajemen keamanan, } \\
\text { manajemen kesehatan, manajemen } \\
\text { kebersihan, manajemen } \\
\text { kesejahteraan, } \\
\text { manajemen akomodasi, manajemen asrama }\end{array}$} & \multirow{8}{*}{$\begin{array}{l}\text { Masyarakat sekitar } \\
\text { Pondok Pesantren, Wali } \\
\text { Santri, Donatur }\end{array}$} \\
\hline Keuangan & & \\
\hline Perekrutan & $\begin{array}{l}\text { Terdiri dari perekrutan santri, perekrutan } \\
\text { staff/pegawai, perekrutan pengajar }\end{array}$ & \\
\hline Pendidikan & \multirow{3}{*}{$\begin{array}{l}\text { Terdiri dari manajemen akademik, } \\
\text { manajemen prasarana pendidikan, } \\
\text { manajemen non klasikal, manajemen } \\
\text { ekstrakurikuler dan bahasa, } \\
\text { manajemen pendidikan dan karakter santri, } \\
\text { manajemen perpustakaan dan laboratorium }\end{array}$} & \\
\hline & & \\
\hline PENDUKUNG & & \\
\hline Sekretaris & $\begin{array}{l}\text { Terdiri dari manajemen administrasi } \\
\text { persuratan, manajemen rapat, manajemen } \\
\text { kegiatan, manajemen kepegawaian }\end{array}$ & \\
\hline Manajemen Hubungan & $\begin{array}{l}\text { Terdiri dari manajemen hubungan yang } \\
\text { berelasi antara orang internal dan eksternal } \\
\text { baik komite maupun wali santri }\end{array}$ & \\
\hline
\end{tabular}




\subsection{Arsitektur Sistem Informasi}

Setelah melakukan identifikasi kebutuhan sistem informasi pondok pesantren, analisis hasil yang penulis dapatkan yakni berupa sitem informasi yang digambarkan pada diagram hirarki guna membantu fungsi bisnis utama dan bisnis pendukung berdasarkan kebutuhan informasi untuk mendukung pertukaran informasi antar fungsi bisnis yang dapat menjadikan pengambilan keputusan. Hirarki sistem informasi ini juga sebagai portofolio usulan penulis dalam perencanaan arsitektur pondok pesantren berdasar 52 standart minimal nasional pada sekolah asrama yang telah di kemas dalam informasi sederhana. Sistem informasi pondok pesantren terbagi menjadi 4 sistem informasi eksekutif, yang terdiri dari sistem informasi eksekutif sekretaris, sistem informasi eksekutif keuangan (bendahara), sistem informasi eksekutif asrama, dan sistem informasi eksekutif hubungan.

Dalam sistem informasi eksekutif juga dibagi dalam beberapa sistem informasi manajemen yang didalamnya dibagi lagi menjadi sub-sub sistem informasi yang dibutuhkan sesuai dengan 52 standart minimal nasional pada sekolah asrama. Pada sistem informasi eksekutif sekretaris di dalamnya terdapat sistem informasi manajemen kesekretariatan, sistem informasi eksekutif keuangan (bendahara) terdapat sistem informasi manajemen keuangan, sistem informasi eksekutif hubungan terdapat sistem informasi manajemen humas, dan pada sistem informasi eksekutif asrama dibagi dalam empat sistem informasi manajemen. antara lain sistem informasi manajemen keamanan, sistem informasi manajemen kesehatan, sistem informasi manajemen asrama, dan sistem informasi manajemen konsumsi. Untuk mengetahui detail arsitektur sistem informasi pondok pesantren, penulis gambarkan pada diagram hirarki sebagai berikut:

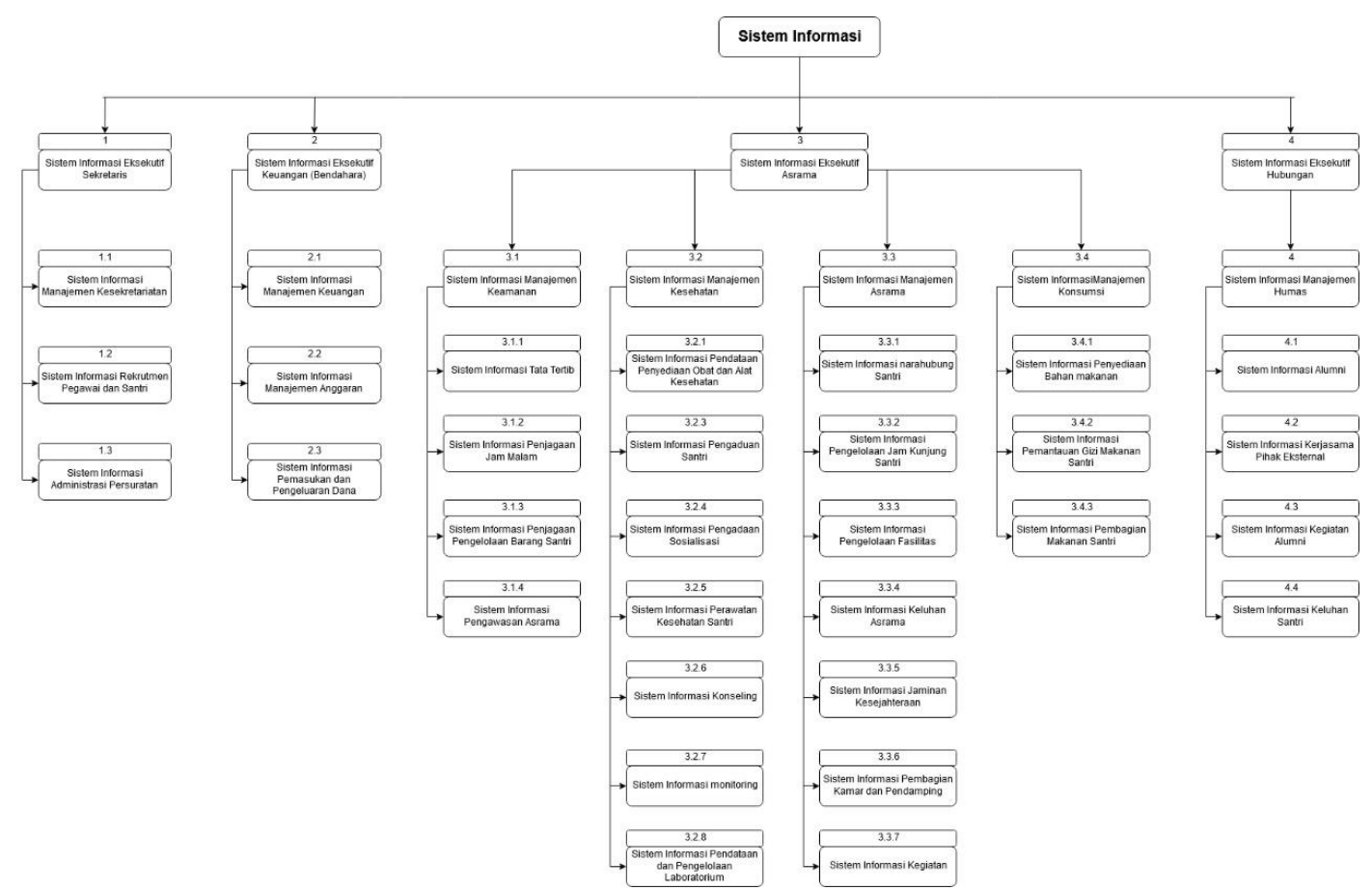

Gambar 4. Diagram Hirarki Sistem Informasi Pondok Pesantren 


\section{SIMPULAN}

Dalam perencanaa fungsi bisnis di pondok pesantren telah dilakukan identifikasi melalui analisis value chain yang menghasilkan sebuah portofolio usulan rancangan sistem informasi pondok pesantren yang sesuai dengan 52 standart minimal nasional pada sekolah [6]. Portofolio tersebut dapat digunakan sebagain acuan dalam mendukung fungsi bisnis pondok pesantren yang dapat membantu semua pihak yang termasuk dalam stakeholder dalam melaksanakan pertukaran informasi antar fungsi bisnis agar lebih lancar, efektif, dan efisien. Hasil penelitian ini dapat digunakan untuk peneliti selanjutnya sebagai acuan dalam membangun dan mengembangkan sistem informasi di suatu pondok pesantren, dan bisa melakukan identifikasi TOGAF ADM dengan lebih rinci.

\section{DAFTAR PUSTAKA}

[1] A. Arum Et Al., "Perencanaan Arsitektur Enterprise Menggunakan Togaf Adm ( Architecture Development Method ) Pada Dinas Kesehatan Kota Salatiga," No. November, 2018.

[2] H. N. Syaddad, "Perancangan Model Arsitektur Sistem Informasi Di Perguruan Tinggi Menggunakan Togaf Architecture Development Methode (Studi Kasus: Universitas Suryakancana )," Vol. 7, No. 2, 2015.

[3] Riza Kurniawan, " Perancangan Arsitektur Enterprise Pada Pondok Pesantren Salafiyah Syafi'iyah Situbondo Dengan", 2013, E-Theses Uin Malang.

[4] D. Irmayanti And B. Permana, "Perencanaan Arsitektur Enterprise Sistem Informasi Disnakersostrans Kabupaten Purwakarta Menggunakan Togaf," Vol. 3, No. 1, Pp. 17-28, 2018.

[5] R. Yunis And K. Surendro, "Perancangan Model Enterprise Architecture Dengan Togaf Architecture Development Method Perancangan Model Enterprise Architecture Dengan Togaf," No. January, 2009.

[6] “Boarding Schools," No. April, Pp. 1-20, 2015. 